\title{
Dispersal of viable row-crop seeds of commercial agriculture by farmland birds: implication for genetically modified crops
}

\author{
John L. CUMMINGS ${ }^{*}$, Levis W. HANDLEY ${ }^{2}$, Bruce MACBRYDE ${ }^{2}$, Shelagh K. TUPPER ${ }^{1}$, Scott J. WERNER ${ }^{1}$ \\ and Zachary J. BYRAM ${ }^{1}$ \\ 1 U.S. Department of Agriculture, Animal and Plant Health Inspection Service, Wildlife Services, National Wildlife Research Center, \\ 4101 LaPorte Avenue, Fort Collins, CO 80521, USA \\ 2 U.S. Department of Agriculture, Animal and Plant Health Inspection Service, Biotechnology Regulatory Services, 4700 River Road, \\ Riverdale, MD 20737, USA
}

To address some concerns about the expansion of genetically engineered pharmaceutical and industrial crops to outdoor plantings and potential impacts on the human food supply, we determined whether commercial agriculture seeds of maize or corn Zea mays L., barley Hordeum vulgare L., safflower Carthamus tinctorius $\mathrm{L}$. and rice Oryza sativa L. are digested or pass viably through the digestive tract, or are transported externally, by captive mallard ducks Anas platyrhynchos L., ring-necked pheasants Phasianus colchicus L., red-winged blackbirds Agelaius phoeniceus (L.) and rock pigeons Columba livia Gmelin (with the exception of whole maize seeds which were too large to feed to the blackbirds). These crop seeds, whether free-fed or force-fed, did not pass through the digestive tract of these bird species. The birds nonetheless did retain viable seeds in the esophagus/crop and gizzard for several hours. For example, after foraging for $6 \mathrm{~h}$, mallards had retained an average of $228 \pm 112$ barley seeds and pheasants $192 \pm 78$ in the esophagus/crop, and their germination rates were 93 and $\mathbf{5 0 \%}$, respectively. Birds externally transported seeds away from the feeding location, but in only four instances were seeds found attached to their muddy feet or legs and in no case to feathers. Risk of such crop seeds germinating, establishing and reproducing off site after transport by a bird (externally or internally) or movement of a carcass by a predator, will depend greatly on the crop and bird species, location, environmental conditions (including soil characteristics), timing, and seed condition.

Keywords: barley / corn / digestion / dispersal / genetically modified organisms / maize / mallard / pharmaceutical and industrial crops / red-winged blackbird / rice / ring-necked pheasant / rock pigeon / safflower / seed / viability

\section{INTRODUCTION}

Agricultural biotechnology offers growers opportunities to improve production efficiency, decrease use of herbicides and pesticides, enhance productivity and increase profits, while offering consumers improved and new products at lower costs (Herdt, 2006). Research has progressed from inserting genes that confer traits like herbicide tolerance and insect and disease resistance that make crops easier to grow, to inserting genes that enable plants to manufacture drugs and industrial chemicals (Dalal et al., 2006). Since the early 1990s, the U.S. Department of Agriculture (USDA) has approved over 200 field trials of pharmaceutical and industrial crop plants (Elbehri, 2005). Companies' reasons for turning

* Corresponding author:

john.1.cummings@aphis.usda.gov to plants as bio-factories include novel products, cheaper production and more flexible manufacturing, which may include the avoidance of technical issues or controversy associated with using animal systems.

Sometimes this realm of development is called molecular farming, or biopharming. Pharmaceutical and industrial crops are considered here to be from plants that have been genetically engineered (genetically modified) to produce medical and industrial precursors or products, including human and veterinary drugs and biologics, and industrial and research chemicals (Fischer et al., 2004; Floss et al., 2007; Goldstein and Thomas, 2004; Han et al., 2006; Ma et al., 2005; Scheller and Conrad, 2005; Smallwood, 2006; Teli and Timko, 2004). Included in the category are crops intentionally inoculated with genetically engineered viruses that, in turn, produce industrial or medical substances in the treated plants (Yusibov et al., 2006). Pharmaceutical and industrial crops are produced 


\section{J.L. Cummings et al.}

by the same basic methods used to genetically engineer food or other crops (Howard and Hood, 2007), and in the USA such crops can be grown commercially outdoors with additional isolating restrictions (APHIS/BRS, 2007).

The food industry, environmental organizations and the U.S. National Research Council have expressed concern about the expansion of pharmaceutical and industrial crops to outdoor (open-field) plantings, as they have the potential to contaminate the human food or livestock feed supply (Freese et al., 2004; NRC, 2002; UCS, 2006); however, there has been a steady development of products in this sector (e.g. Einsiedel and Medlock, 2005; Mewett et al., 2007; Moschini, 2006; Spök, 2007). Despite the perceived risk from pharmaceutical and industrial crops, the magnitude of possible risks depend on many factors, including the products produced, the organisms and environments involved, and the scale, level and duration of exposure (Chakauya et al., 2006; Howard and Hood, 2007; Mascia and Flavell, 2004; Murphy, 2007; Peterson and Arntzen, 2004).

Wildlife, particularly birds, that would ingest viable seeds from pharmaceutical and industrial crops are a potential route toward human and livestock exposure. Furthermore, viable seeds may be transported away from the cultivated field in three possible ways: (1) physically on a bird's feet or feathers; (2) by remaining in the esophagus/crop or gizzard and being relevant in the fate of the carcass; or (3) passing intact through the digestive tract and being deposited as fecal material.

Seeds constitute the major food of many birds, making up practically the entire diet of some common species (Bent, 1932/1963). Agricultural crops that are intended for human or domestic livestock consumption are quite appealing to some birds (Holland et al., 2006; Martin et al., 1951/1961; Prosser and Hart, 2005). Among these crops are maize, bread wheat Triticum aestivum L., barley, oats Avena sativa L., safflower, rice, sorghum Sorghum bicolor (L.) Moench and other grains (Pinowski and Summers-Smith, 1990). Blackbirds and waterfowl consume large amounts of ripening grains and in some areas of the USA they are considered pests. For example, economic losses due to blackbird depredations on rice in USA are estimated at US \$ 21 million annually (Cummings et al., 2005). After harvest, waste rice remaining in the fields can be a significant source of food for waterfowl (Manley et al., 2004; Stafford et al., 2006). Post-harvest birds in agricultural fields can be beneficial in some situations by gleaning crop seeds not removed by mechanical harvesting and thus reducing the potential for volunteers in a subsequent growing season.

Ridley (1930) suggested that the wide distribution of aquatic plants and small-seeded marsh plants is due to waterfowl, and many studies have borne this out
(Charalambidou and Santamaría, 2002; Figuerola and Green, 2002a; Green et al., 2002). Considerable research has documented the role of mallards in dispersal of such seeds (e.g. Charalambidou et al., 2003; Figuerola et al., 2002, 2003; Mueller and van der Valk, 2002; Santamaría et al., 2002). Waterfowl are often blamed for the introduction and distribution of weed seed in rice fields (Powers et al., 1978). Migratory waterfowl can potentially transport seeds considerable distances (Dolbeer, 1978). Mallards have been documented flying at $65-80 \mathrm{~km} \cdot \mathrm{h}^{-1}$ and during migration have moved from $445 \mathrm{~km}$ (Cooke, 1940) up to $1600 \mathrm{~km}$ (Bellrose and Sieh, 1960) in a day. Nonetheless, most of the seeds dispersed by waterfowl are likely to be deposited within $300 \mathrm{~km}$ of their source (Clausen et al., 2002).

At rice harvest in southern USA, local rather than migrating blackbirds may be more responsible for damage (Brugger and Dolbeer, 1990). Feral rock pigeons, although often local, may fly as far as $18-25 \mathrm{~km}$ to foraging sites (Pierson et al., 1976; Rose et al., 2006). Migration often coincides with harvest of commercial agricultural crops. Birds such as blackbirds can potentially transport seeds considerable distances (Dolbeer, 1978). In addition, mortality caused by avian or mammalian predators, human hunters or accidents could influence avian dispersal of seeds.

Studies of digestibility and dispersal of seeds by birds have focused mainly on wild plants (Malone, 1965; Proctor, 1964, 1966; Swank, 1944; Traveset, 1998). Results indicate that the species and size of the bird and hardness and size of the seed, as well as typical diet, can be important factors determining whether and when a viable seed passes through a bird's digestive tract. However, there is little definitive information on bird transport or digestion of seeds from annual row crops such as maize, wheat, rice, sorghum, barley and safflower.

This study was conducted to determine the potential for ecologically diverse farmland birds in the USA - mallard ducks, ring-necked pheasants, red-winged blackbirds and rock pigeons (which include feral pigeons and homing pigeons) - to transport commercial maize, barley and rice caryopses and safflower achenes, both being seedlike fruits often regarded as seeds. Agricultural lines of these annual row-crops are in development for pharmaceutical and/or industrial purposes, and a few pharmaceutical lines of maize are in the testing phase (Elbehri, 2005; Murphy, 2007). These species of birds are considered fairly representative of most bird species that would be foraging in agricultural row-crop fields in the continental USA during pre-harvest, harvest and post-harvest.

Five experiments were conducted to determine if (1) viable seeds of commercial maize, barley, safflower and rice pass through the digestive tract of captive mallards, ring-necked pheasants, red-winged blackbirds and rock 
Table 1. Experiment 1: Consumption of commercial seeds of maize, barley, safflower and rice by captive mallards, ring-necked pheasants, red-winged blackbirds and rock pigeons over daily 2-h feeding period and number of intact seeds passed through the digestive tract during entire 3 -day test.

\begin{tabular}{|c|c|c|c|c|c|c|}
\hline $\begin{array}{l}\text { Species }^{1} \\
(n=10)\end{array}$ & $\begin{array}{l}\text { Seed } \\
\text { type }\end{array}$ & $\begin{array}{c}\text { Seed } \\
\text { weight } \\
\text { offered }(\mathrm{g})\end{array}$ & $\begin{array}{c}\text { Average } \\
\text { consumption } \\
(\mathrm{g} \pm \mathrm{SE})\end{array}$ & $\begin{array}{c}\begin{array}{c}\text { Average } \\
\text { consumption } \\
(\text { no. }\end{array} \\
\text { seeds } \pm \mathrm{SE})^{2}\end{array}$ & $\begin{array}{c}\text { Recovered } \\
\text { feces } \\
\text { weight } \\
(\mathrm{g} \pm \mathrm{SE})\end{array}$ & $\begin{array}{c}\text { No. seeds } \\
\text { recovered } \\
\text { from } \\
\text { feces }\end{array}$ \\
\hline mallard & maize & 200.0 & $6.0 \pm 1.4$ & $22.5 \pm 5.2$ & $0.9 \pm 0.2$ & 0 \\
\hline " & barley & 200.0 & $10.2 \pm 0.9$ & $212.3 \pm 19.4$ & $1.3 \pm 0.2$ & 0 \\
\hline$"$ & safflower & 200.0 & $6.2 \pm 1.2$ & $130.9 \pm 26.0$ & $1.9 \pm 0.3$ & 0 \\
\hline " & rice & 200.0 & $21.0 \pm 1.2$ & $876.1 \pm 47.0$ & $2.8 \pm 0.5$ & 0 \\
\hline pheasant & maize & 200.0 & $13.9 \pm 1.6$ & $52.4 \pm 6.0$ & $2.9 \pm 0.5$ & 0 \\
\hline " & barley & 200.0 & $9.9 \pm 1.2$ & $206.9 \pm 24.0$ & $4.5 \pm 0.6$ & 0 \\
\hline " & safflower & 200.0 & $14.3 \pm 1.3$ & $304.5 \pm 27.6$ & $8.0 \pm 0.7$ & 0 \\
\hline " & rice & 200.0 & $13.1 \pm 1.4$ & $529.0 \pm 52.0$ & $3.6 \pm 0.4$ & 0 \\
\hline blackbird & maize & 0.0 & na & na & na & na \\
\hline$"$ & 0.9 barley & 50.0 & $0.5 \pm 0.1$ & $10.5 \pm 3.1$ & $0.4 \pm 0.2$ & na \\
\hline$"$ & safflower & 50.0 & $1.8 \pm 0.3$ & $38.3 \pm 6.8$ & $0.2 \pm 0.04$ & na \\
\hline$"$ & rice & 50.0 & $2.4 \pm 0.5$ & $99.0 \pm 21.0$ & $0.3 \pm 0.05$ & na \\
\hline pigeon & maize & 50.0 & $4.0 \pm 0.6$ & $18.1 \pm 2.3$ & $1.9 \pm 0.1$ & 0 \\
\hline$"$ & barley & 50.0 & $4.8 \pm 0.7$ & $82.3 \pm 14.0$ & $1.3 \pm 0.3$ & 0 \\
\hline " & safflower & 50.0 & $6.0 \pm 0.8$ & $114.1 \pm 16.6$ & $2.2 \pm 0.4$ & 0 \\
\hline " & rice & 50.0 & $5.4 \pm 0.8$ & $251.4 \pm 30.1$ & $2.9 \pm 0.3$ & 0 \\
\hline
\end{tabular}

${ }^{1}$ Mallard = Anas platyrhynchos, ring-necked pheasant $=$ Phasianus colchicus, red-winged blackbird = Agelaius phoeniceus, rock pigeon $=$ Columba livia .

${ }^{2}$ Average weight individual seeds: maize $=0.266 \mathrm{~g}$, barley $=0.048 \mathrm{~g}$, safflower $=0.047 \mathrm{~g}$, rice $=0.026 \mathrm{~g}$.

${ }^{3}$ na $=$ Not applicable.

pigeons; (2) seeds of these four crops that were recovered from the esophagus/crop and gizzard of these four farmland bird species remained viable; and (3) viable seeds of these four crops can be physically transported on feet and feathers of these four bird species. The Materials and Methods section provides full details of the experimental procedures.

\section{RESULTS}

\section{Experiment 1: Repeated daily free feeding for 2 hours}

Captive mallards, pheasants, blackbirds and pigeons that fed freely for $2 \mathrm{~h}$ each day on commercial seeds of maize, barley, safflower and rice did not pass any of these seeds intact through the digestive tract (see Tab. 1). For example, individual mallards consumed daily an average of $22 \pm 5,212 \pm 19,131 \pm 26$ and $876 \pm 47$ seeds $(6.0 \pm 1.4$, $10.2 \pm 0.9,6.2 \pm 1.2$ and $21.0 \pm 1.2 \mathrm{~g})$ of maize, barley, safflower and rice, respectively, producing an average of $0.9 \pm 0.2,1.3 \pm 0.2,1.9 \pm 0.3$ and $2.8 \pm 0.5 \mathrm{~g}$ of feces daily. No intact seeds were recovered from the feces of any test bird; there was no germination testing.

\section{Experiment 2: Orally gavaged seeds}

Mallards, pheasants, blackbirds and pigeons orally gavaged (force-fed) with seeds of maize, barley, safflower and rice also did not pass any seeds intact through the digestive tract (see Tab. 2). For example, individual pheasants orally gavaged with 50 seeds of their assigned seed type produced a daily average of $24.3 \pm 2.3,21.7 \pm 2.6$, $23.6 \pm 2.7$ and $18.5 \pm 1.9 \mathrm{~g}$ of feces, respectively. No intact seeds were recovered from the feces of any test bird; there was no germination testing.

\section{Experiment 3A: Single free feeding for 2 hours}

The number of seeds consumed during $2 \mathrm{~h}$ of free feeding varied by seed type and bird species (see Tab. 3). Mallards, the species with the greatest consumption, consumed an average of $42 \pm 6$ maize, $479 \pm 20$ barley, $136 \pm 25$ safflower and $758 \pm 27$ rice seeds in $2 \mathrm{~h}$. The average number of intact seeds recovered from the esophagus/crop and the gizzard of each species ranged from 0 to $237 \pm 11$ and 0 to $29 \pm 1$, respectively. Seeds recovered from the esophagus/crop represented 0 to $34 \%$ of the seeds consumed. 


\section{J.L. Cummings et al.}

Table 2. Experiment 2: Number of orally gavaged commercial seeds of maize, barley, safflower and rice passed intact through the digestive tract of captive mallards, ring-necked pheasants, red-winged blackbirds and rock pigeons during entire 3-day test.

\begin{tabular}{|c|c|c|c|c|c|}
\hline $\begin{array}{l}\text { Species }^{1} \\
(n=10)\end{array}$ & $\begin{array}{l}\text { Seed } \\
\text { type }\end{array}$ & $\begin{array}{c}\text { No. seeds } \\
\text { gavaged }\end{array}$ & $\begin{array}{c}\text { Average seeds } \\
\text { regurgitated } \\
(\text { no. seeds } \pm \mathrm{SE})\end{array}$ & $\begin{array}{l}\text { Recovered } \\
\text { feces } \\
\text { weight } \\
(\mathrm{g} \pm \mathrm{SE})\end{array}$ & $\begin{array}{l}\text { No. seeds } \\
\text { recovered } \\
\text { from feces }\end{array}$ \\
\hline mallard & maize & 50 & $0.0 \pm 0.00$ & $20.9 \pm 3.6$ & 0 \\
\hline$"$ & barley & 50 & $0.1 \pm 0.07$ & $36.6 \pm 4.7$ & 0 \\
\hline$"$ & safflower & 50 & $0.0 \pm 0.00$ & $49.3 \pm 4.9$ & 0 \\
\hline$"$ & rice & 50 & $0.0 \pm 0.03$ & $41.5 \pm 5.2$ & 0 \\
\hline pheasant & maize & 50 & $0.1 \pm 0.07$ & $24.3 \pm 2.3$ & 0 \\
\hline " & barley & 50 & $0.2 \pm 0.08$ & $21.7 \pm 2.6$ & 0 \\
\hline$"$ & safflower & 50 & $0.2 \pm 0.12$ & $23.6 \pm 2.7$ & 0 \\
\hline$"$ & rice & 50 & $0.3 \pm 0.14$ & $18.5 \pm 1.9$ & 0 \\
\hline blackbird & maize & 0 & na & na & na \\
\hline " & barley & 20 & $5.5 \pm 1.53$ & $0.6 \pm 0.1$ & 0 \\
\hline$"$ & safflower & 20 & $3.7 \pm 0.85$ & $0.3 \pm 0.1$ & 0 \\
\hline$"$ & rice & 20 & $1.5 \pm 0.67$ & $0.4 \pm 0.1$ & 0 \\
\hline pigeon & maize & 20 & $0.0 \pm 0.00$ & $12.6 \pm 1.3$ & 0 \\
\hline$"$ & barley & 20 & $0.0 \pm 0.00$ & $19.7 \pm 0.2$ & 0 \\
\hline$"$ & safflower & 20 & $0.0 \pm 0.00$ & $18.2 \pm 1.3$ & 0 \\
\hline$"$ & rice & 20 & $0.3 \pm 0.22$ & $21.0 \pm 1.8$ & 0 \\
\hline
\end{tabular}

${ }^{1}$ Mallard = Anas platyrhynchos, ring-necked pheasant = Phasianus colchicus, red-winged blackbird = Agelaius phoeniceus, rock pigeon $=$ Columba livia .

${ }^{2}$ na $=$ Not applicable.

The germination rate of maize, barley, safflower and rice seeds recovered from the esophagus/crop and the gizzard of mallards, pheasants, blackbirds and pigeons after the $2 \mathrm{~h}$ also varied among bird species and seed types (Tab. 3). For example, pigeons consumed an average of $15 \pm 2$ maize and $117 \pm 8$ rice seeds. The germination rate of these seed types recovered from the crop was 100 and $7 \%$, respectively. However, from the gizzard, recovered maize seeds did not germinate, whereas rice seeds had a $15 \%$ germination rate.

\section{Experiment 3B: Single free feeding for 6 hours}

The average seed consumption by all birds after $6 \mathrm{~h}$ of free feeding increased approximately $58 \%$ over $2 \mathrm{~h}$ of free feeding (see Tab. 4). The average number of intact seeds recovered from the esophagus/crop and the gizzard of each species after $6 \mathrm{~h}$ ranged from 0 to $317 \pm 19$ and from 0 to $40 \pm 2$, respectively. Seeds recovered from the esophagus/crop of all species represented 0 to $46 \%$ of the seeds consumed.

The germination rate of maize, barley, safflower and rice seeds recovered from the esophagus/crop and gizzard of mallards, pheasants, blackbirds and pigeons after $6 \mathrm{~h}$ also varied among bird species and seed types (Tab. 4).
For the three species that consumed maize, the germination rate of seeds recovered from the esophagus/crop was $>99 \%$, but the rate varied from 0 to $64 \%$ for seeds recovered from the gizzard. For example, mallards consumed an average of $69 \pm 11$ maize, $625 \pm 64$ barley, $558 \pm 54$ safflower and $1580 \pm 55$ rice seeds. The germination rate of these seeds recovered from the esophagus was respectively $100,93,16$ and $14 \%$, whereas it was respectively $64,25,4$ and $10 \%$ for these seeds recovered from the gizzard.

\section{Experiment 4: Seed adhesion and transport}

Mallards, pheasants, blackbirds and pigeons all physically transported seeds from test pans filled with wet heavy clay/gumbo soil to other parts of their cages (see Tab. 5), by scattering and on their muddy feet or legs. The distance seeds were transported varied from the edge of the test pan to the perimeter of the cage, i.e. to $1.5 \mathrm{~m}$ or more. The abrasive action of the cage's concrete floor dislodged seeds from the birds. Only pheasants and pigeons transported seeds on their feet and legs. Pheasants transported the most seeds: an average of $0.9 \pm 0.4$ maize, $6.3 \pm 1.3$ barley, $10.1 \pm 3.5$ safflower and $13.1 \pm 3.4$ rice seeds. Pheasants also had the greatest amount of soil attached to their feet and legs, and 4 of 10 were found with 
Table 3. Experiment 3A: Number of intact commercial seeds of maize, barley, safflower and rice recovered from the esophagus/crop and the gizzard of captive mallards, ring-necked pheasants, red-winged blackbirds and rock pigeons and number germinated after $2 \mathrm{~h}$ of food availability.

\begin{tabular}{|c|c|c|c|c|c|c|c|c|c|c|c|}
\hline \multirow{2}{*}{$\begin{array}{l}\text { Species }^{1} \\
(n=10)\end{array}$} & \multirow{2}{*}{$\begin{array}{l}\text { Seed } \\
\text { type }\end{array}$} & \multirow{2}{*}{$\begin{array}{c}\text { Average } \\
\text { consumption } \\
(\mathrm{g} \pm \mathrm{SE})\end{array}$} & \multirow{2}{*}{$\begin{array}{c}\text { Average } \\
\text { consumption } \\
(\text { no. seeds } \pm \mathrm{SE})^{2}\end{array}$} & \multicolumn{2}{|c|}{$\begin{array}{c}\text { Average no. } \\
\text { seeds recovered }\end{array}$} & \multicolumn{2}{|c|}{$\begin{array}{l}\text { Average no. } \\
\text { seeds plated }\end{array}$} & \multicolumn{2}{|c|}{$\begin{array}{c}\text { Average no. } \\
\text { seeds germinated }\end{array}$} & \multicolumn{2}{|c|}{$\begin{array}{c}\text { Percent } \\
\text { germinated }\end{array}$} \\
\hline & & & & $\begin{array}{c}\text { Esophagus/ } \\
\text { Crop }\end{array}$ & Gizzard & $\begin{array}{c}\text { Esophagus/ } \\
\text { Crop }\end{array}$ & Gizzard & $\begin{array}{c}\text { Esophagus/ } \\
\text { Crop }\end{array}$ & Gizzard & $\begin{array}{c}\text { Esophagus/ } \\
\text { Crop }\end{array}$ & Gizzard \\
\hline mallard & maize & $11.4 \pm 1.6$ & $42.9 \pm 6.2$ & $5.2 \pm 3.1$ & $1.6 \pm 0.7$ & $5.2 \pm 3.1$ & $1.6 \pm 0.7$ & $5.2 \pm 3.1$ & $0.8 \pm 0.4$ & $100 \%$ & $50 \%$ \\
\hline$"$ & barley & $23.0 \pm 1.0$ & $479.6 \pm 20.5$ & $237.8 \pm 48.5$ & $24.4 \pm 4.7$ & $237.8 \pm 48.5$ & $24.4 \pm 4.7$ & $218.2 \pm 49.8$ & $7.0 \pm 2.4$ & $92 \%$ & $29 \%$ \\
\hline$"$ & safflower & $6.4 \pm 1.2$ & $136.6 \pm 25.6$ & $30.8 \pm 26.6$ & $7.2 \pm 3.0$ & $30.8 \pm 26.6$ & $7.2 \pm 3.0$ & $7.2 \pm 6.7$ & $1.6 \pm 1.4$ & $23 \%$ & $22 \%$ \\
\hline " & rice & $18.2 \pm 0.7$ & $758.3 \pm 27.4$ & $159.6 \pm 65.6$ & $15.2 \pm 4.3$ & $159.6 \pm 65.6$ & $15.2 \pm 4.3$ & $8.8 \pm 4.1$ & $0.4 \pm 0.4$ & $6 \%$ & $3 \%$ \\
\hline pheasant & maize & $10.6 \pm 0.9$ & $40.0 \pm 3.5$ & $18.2 \pm 6.6$ & $2.8 \pm 0.7$ & $18.2 \pm 6.6$ & $2.8 \pm 0.7$ & $18.2 \pm 6.6$ & $0.4 \pm 0.4$ & $100 \%$ & $14 \%$ \\
\hline$"$ & safflower & $9.0 \pm 1.2$ & $191.9 \pm 24.9$ & $105.8 \pm 50.9$ & $4.8 \pm 2.1$ & $105.8 \pm 50.9$ & $4.8 \pm 2.1$ & $32.4 \pm 17.5$ & $0.4 \pm 0.4$ & $31 \%$ & $8 \%$ \\
\hline$"$ & rice & $9.0 \pm 0.9$ & $374.2 \pm 35.8$ & $134.8 \pm 70.4$ & $9.4 \pm 5.4$ & $134.8 \pm 70.4$ & $9.4 \pm 5.4$ & $6.8 \pm 4.0$ & $0.2 \pm 0.2$ & $5 \%$ & $2 \%$ \\
\hline blackbird & maize & na & na & na & na & na & na & na & na & na & na \\
\hline$"$ & barley & $0.4 \pm 0.1$ & $8.3 \pm 0.8$ & $0.0 \pm 0.0$ & $1.2 \pm 0.7$ & $\ldots$ & $1.2 \pm 0.7$ & $\ldots$ & $0.0 \pm 0.0$ & $\ldots$ & $0 \%$ \\
\hline$"$ & safflower & $1.1 \pm 0.0$ & $22.6 \pm 5.8$ & $0.0 \pm 0.0$ & $0.0 \pm 0.0$ & $\ldots$ & $0.0 \pm 0.0$ & $\cdots$ & $\cdots$ & $\cdots$ & $\ldots$ \\
\hline " & rice & $1.7 \pm 0.3$ & $70.0 \pm 19.1$ & $0.0 \pm 0.0$ & $0.4 \pm 0.4$ & $\cdots$ & $0.4 \pm 0.4$ & & $0.0 \pm 0.0$ & $\cdots$ & $0 \%$ \\
\hline pigeon & maize & $4.1 \pm 0.5$ & $15.3 \pm 1.9$ & $7.2 \pm 2.7$ & $0.8 \pm 0.2$ & $7.2 \pm 2.7$ & $0.8 \pm 0.2$ & $7.2 \pm 2.7$ & $0.0 \pm 0.0$ & $100 \%$ & $0 \%$ \\
\hline " & barley & $2.7 \pm 0.3$ & $56.7 \pm 5.4$ & $28.4 \pm 11.5$ & $10.0 \pm 1.4$ & $28.4 \pm 11.5$ & $10.0 \pm 1.4$ & $22.8 \pm 9.6$ & $1.2 \pm 0.7$ & $80 \%$ & $12 \%$ \\
\hline$"$ & rice & $2.8 \pm 0.2$ & $116.7 \pm 8.0$ & $34.8 \pm 20.8$ & $5.2 \pm 1.2$ & $34.8 \pm 20.8$ & $5.2 \pm 1.2$ & $2.6 \pm 1.7$ & $0.8 \pm 0.4$ & $7 \%$ & $15 \%$ \\
\hline
\end{tabular}

${ }^{1}$ Mallard = Anas platyrhynchos, ring-necked pheasant $=$ Phasianus colchicus, red-winged blackbird = Agelaius phoeniceus, rock pigeon $=$ Columba livia .

${ }^{2}$ Average weight individual seeds: maize $=0.266 \mathrm{~g}$, barley $=0.048 \mathrm{~g}$, safflower $=0.047 \mathrm{~g}$, rice $=0.026 \mathrm{~g}$. 
Table 4. Experiment 3B: Number of intact commercial seeds of maize, barley, safflower and rice recovered from the esophagus/crop and the gizzard of captive mallards, ring-necked pheasants, red-winged blackbirds and rock pigeons and number germinated after $6 \mathrm{~h}$ of food availability.

\begin{tabular}{|c|c|c|c|c|c|c|c|c|c|c|c|}
\hline \multirow{2}{*}{$\begin{array}{l}\text { Species }^{1} \\
(n=10)\end{array}$} & \multirow{2}{*}{$\begin{array}{l}\text { Seed } \\
\text { type }\end{array}$} & \multirow{2}{*}{$\begin{array}{c}\text { Average } \\
\text { consumption } \\
(\mathrm{g} \pm \mathrm{SE})\end{array}$} & \multirow{2}{*}{$\begin{array}{c}\text { Average } \\
\text { consumption } \\
(\text { no. } \text { seeds } \pm \text { SE })^{2}\end{array}$} & \multicolumn{2}{|c|}{$\begin{array}{c}\text { Average no. } \\
\text { seeds recovered }\end{array}$} & \multicolumn{2}{|c|}{$\begin{array}{l}\text { Average no. } \\
\text { seeds plated }\end{array}$} & \multicolumn{2}{|c|}{$\begin{array}{c}\text { Average no. } \\
\text { seeds germinated }\end{array}$} & \multicolumn{2}{|c|}{$\begin{array}{c}\text { Percent } \\
\text { germinated }\end{array}$} \\
\hline & & & & $\begin{array}{l}\text { Esophagus/ } \\
\text { Crop }\end{array}$ & Gizzard & $\begin{array}{l}\text { Esophagus/ } \\
\text { Crop }\end{array}$ & Gizzard & $\begin{array}{l}\text { Esophagus/ } \\
\text { Crop }\end{array}$ & Gizzard & $\begin{array}{c}\text { Esophagus/ } \\
\text { Crop }\end{array}$ & Gizzard \\
\hline mallard & maize & $18.5 \pm 3.1$ & $69.5 \pm 11.6$ & $13.2 \pm 8.8$ & $2.2 \pm 1.2$ & $13.2 \pm 8.8$ & $2.2 \pm 1.2$ & $13.2 \pm 8.8$ & $1.4 \pm 0.9$ & $100 \%$ & $64 \%$ \\
\hline$"$ & barley & $30.0 \pm 3.1$ & $625.0 \pm 64.3$ & $228.8 \pm 112.1$ & $22.0 \pm 5.8$ & $228.8 \pm 112.1$ & $22.0 \pm 5.8$ & $213.4 \pm 108.0$ & $5.4 \pm 1.6$ & $93 \%$ & $25 \%$ \\
\hline$"$ & safflower & $26.2 \pm 2.5$ & $558.3 \pm 54.0$ & $145.2 \pm 62.1$ & $11.2 \pm 5.4$ & $145.2 \pm 62.1$ & $11.2 \pm 5.4$ & $23.2 \pm 10.7$ & $0.4 \pm 0.4$ & $16 \%$ & $4 \%$ \\
\hline$"$ & rice & $37.9 \pm 1.4$ & $1580.8 \pm 55.5$ & $259.0 \pm 112.8$ & $29.4 \pm 5.0$ & $259.0 \pm 112.8$ & $29.4 \pm 5.0$ & $36.8 \pm 16.8$ & $2.8 \pm 0.8$ & $14 \%$ & $10 \%$ \\
\hline pheasant & maize & $24.3 \pm 2.0$ & $91.2 \pm 7.7$ & $41.8 \pm 11.2$ & $4.4 \pm 1.2$ & $41.8 \pm 11.2$ & $4.4 \pm 1.2$ & $41.4 \pm 11.1$ & $1.0 \pm 0.5$ & $99 \%$ & $23 \%$ \\
\hline$"$ & barley & $19.8 \pm 2.2$ & $412.1 \pm 46.0$ & $192.6 \pm 78.0$ & $40.4 \pm 11.2$ & $192.6 \pm 78.0$ & $40.4 \pm 11.2$ & $95.4 \pm 39.8$ & $5.4 \pm 3.1$ & $50 \%$ & $13 \%$ \\
\hline$"$ & safflower & $25.4 \pm 1.9$ & $540.9 \pm 39.6$ & $238.6 \pm 64.2$ & $9.0 \pm 2.3$ & $238.6 \pm 64.2$ & $9.0 \pm 2.3$ & $48.2 \pm 18.5$ & $0.8 \pm 0.4$ & $20 \%$ & $9 \%$ \\
\hline$"$ & rice & $25.9 \pm 1.4$ & $1080.8 \pm 52.0$ & $317.4 \pm 137.5$ & $18.0 \pm 10.7$ & $317.4 \pm 137.5$ & $18.0 \pm 10.7$ & $11.8 \pm 4.2$ & $0.0 \pm 0.0$ & $4 \%$ & $0 \%$ \\
\hline blackbird & maize & $\mathrm{n}$ & na & na & na & na & na & na & na & na & na \\
\hline$"$ & barley & $1.8 \pm 0.2$ & $37.5 \pm 5.3$ & $0.0 \pm 0.0$ & $2.6 \pm 1.3$ & $0.0 \pm 0.0$ & $2.6 \pm 1.3$ & $\ldots$ & $0.0 \pm 0.0$ & $\cdots$ & $0 \%$ \\
\hline$"$ & safflower & $4.9 \pm 0.3$ & $103.4 \pm 3.5$ & $0.0 \pm 0.0$ & $0.0 \pm 0.0$ & $0.0 \pm 0.0$ & $0.0 \pm 0.0$ & $\ldots$ & $\ldots$ & $\ldots$ & $\ldots$ \\
\hline$"$ & rice & $7.3 \pm 0.2$ & $305.0 \pm 34.9$ & $7.8 \pm 6.4$ & $2.0 \pm 1.5$ & $7.8 \pm 6.4$ & $2.0 \pm 1.5$ & $6.2 \pm 6.0$ & $1.4 \pm 1.2$ & $79 \%$ & $70 \%$ \\
\hline pigeon & maize & $7.2 \pm 0.9$ & $27.1 \pm 3.4$ & $11.0 \pm 4.7$ & $0.6 \pm 0.4$ & $11.0 \pm 4.7$ & $0.6 \pm 0.4$ & $11.0 \pm 4.7$ & $0.0 \pm 0.0$ & $100 \%$ & $0 \%$ \\
\hline$"$ & barley & $7.2 \pm 0.4$ & $149.2 \pm 8.7$ & $54.6 \pm 12.0$ & $7.2 \pm 1.2$ & $54.6 \pm 12.0$ & $7.2 \pm 1.2$ & $36.2 \pm 8.5$ & $0.2 \pm 0.2$ & $66 \%$ & $3 \%$ \\
\hline$"$ & safflower & $7.9 \pm 0.3$ & $168.1 \pm 6.6$ & $62.2 \pm 8.5$ & $1.4 \pm 0.5$ & $62.2 \pm 8.5$ & $1.4 \pm 0.5$ & $18.4 \pm 3.3$ & $0.4 \pm 0.4$ & $30 \%$ & $29 \%$ \\
\hline$"$ & rice & $6.5 \pm 0.4$ & $271.7 \pm 17.2$ & $80.6 \pm 22.0$ & $8.2 \pm 2.1$ & $80.6 \pm 22.0$ & $8.2 \pm 2.1$ & $7.8 \pm 2.3$ & $0.2 \pm 0.2$ & $10 \%$ & $2 \%$ \\
\hline
\end{tabular}

${ }^{1}$ Mallard = Anas platyrhynchos, ring-necked pheasant = Phasianus colchicus, red-winged blackbird = Agelaius phoeniceus, rock pigeon $=$ Columba livia .

${ }^{2}$ Average weight individual seeds: maize $=0.266 \mathrm{~g}$, barley $=0.048 \mathrm{~g}$, safflower $=0.047 \mathrm{~g}$, rice $=0.026 \mathrm{~g}$.

${ }^{3}$ na $=$ Not applicable. 
Table 5. Experiment 4: Transport of commercial seeds of maize, barley, safflower and rice by captive mallards, ring-necked pheasants, red-winged blackbirds and rock pigeons off test pans filled with wet heavy clay/gumbo soil during entire 3-day test.

\begin{tabular}{|c|c|c|c|}
\hline $\begin{array}{l}\text { Species }^{1} \\
(n=10)\end{array}$ & $\begin{array}{l}\text { Seed } \\
\text { type }\end{array}$ & $\begin{array}{l}\text { Average number } \\
\text { seeds transported } \\
\text { (SE) }\end{array}$ & $\begin{array}{l}\text { Seeds found attached } \\
\text { to the body }\end{array}$ \\
\hline mallard & maize & $4.5 \pm 2.1$ & 0 \\
\hline$"$ & barley & $1.7 \pm 0.8$ & 0 \\
\hline$"$ & safflower & $6.5 \pm 3.1$ & 0 \\
\hline$"$ & rice & $1.3 \pm 1.1$ & 0 \\
\hline pheasant & maize & $0.9 \pm 0.4$ & 0 \\
\hline " & barley & $6.3 \pm 1.3$ & $2^{2}$ \\
\hline " & safflower & $10.1 \pm 3.5$ & $2^{2}$ \\
\hline$"$ & rice & $13.1 \pm 3.4$ & $5^{2}$ \\
\hline blackbird & maize & na & na \\
\hline$"$ & barley & na & na \\
\hline$"$ & safflower & $33.0 \pm 31.5$ & 0 \\
\hline$"$ & rice & $10.7 \pm 7.4$ & 0 \\
\hline pigeon & maize & $1.2 \pm 0.8$ & 0 \\
\hline$"$ & barley & $2.1 \pm 0.5$ & 0 \\
\hline$"$ & safflower & $1.3 \pm 0.7$ & 0 \\
\hline$"$ & rice & $10.5 \pm 3.7$ & $2^{2}$ \\
\hline
\end{tabular}

${ }^{1}$ Mallard = Anas platyrhynchos, ring-necked pheasant = Phasianus colchicus, red-winged blackbird = Agelaius phoeniceus, rock pigeon = Columba livia .

${ }^{2}$ Seeds encased in mud attached to feet or legs.

${ }^{3}$ na $=$ Not applicable.

1 or 2 seeds encased in soil attached to the feet or legs. No seeds were observed or found adhering to feathers.

\section{DISCUSSION}

\section{Primary seed dispersal}

Seeds are a major food of many birds and comprise practically the entire diet of some species (e.g. Bent, 1932/1963, 1958/1965; Holland et al., 2006). Numerous studies have documented that birds disperse a wide variety of seed types (e.g. McAtee, 1947; van der Pijl, 1982). The physical properties of seeds influence their passage through the digestive tract (Powers et al., 1978; Traveset, 1998). Small seeds (1-3 mm) with hard seed coats pass through the digestive tract of many species of birds. In some cases the digestive action enhances the germinability of seeds by softening or removing the seed coat. However, seeds produced by many commercial agriculture crops do not have hard seed coats and are readily digestible (Desai, 2004; M. Dideriksen, 2007, pers. comm., USDA/ARS National Center for Genetic Resources Preservation, Fort Collins, Colorado). As shown in our study, commercial maize, barley, safflower and rice seeds did not pass through the digestive tract of mallards, pheasants, blackbirds or pigeons.
Although studying digestion rather than dispersal, Clark and Gentle (1990) did not report passage of any seeds of barley or durum wheat (Triticum durum Desf.) through the gut of captive mallards. In a study focused on gut passage plasticity in response to a seedbased or an animal-based diet, Charalambidou et al. (2005) fed captive mallards simultaneously commercial mixed grains and seeds of wild fennel-leaf or sago false pondweed Stuckenia pectinata (L.) Börner, but only reported on the passage of the wild seeds; some of the other seeds passed through, but most if not all looked damaged and none were tested (Santamaría, 2007 pers. comm.).

\section{Secondary seed dispersal}

Although many factors are involved, making it extremely variable, food items can take an average of $4 \mathrm{~h}$ to pass through the digestive system of some birds (Sibbald, 1979). In mallards, the digestive tract itself is known to have considerable plasticity in response to diet, and the seed retention time can vary greatly (Charalambidou et al., 2005). Based on the feces voided, commercial grain digestion by mallards is considered rapid (Clark and Gentle, 1990).

However, birds can retain viable seeds in the esophagus/crop and the gizzard for a while (Charalambidou 


\section{J.L. Cummings et al.}

and Santamaría, 2002). In our study, after $6 \mathrm{~h}$ all the bird species retained some viable seeds of at least one of the cultivated species in the esophagus/crop and in the gizzard (Tab. 4). This is long enough that the bird (e.g. carcass or its digestive tract) could have moved a considerable distance. Thus, although unlikely, viable seeds in birds that are killed by predators, hunters or accidents (cf. DeVault et al., 2003; Nogales et al., 1996, 2002; Peterson et al., 2001) might still have potential to germinate and establish - if encountering favorable environmental conditions.

In primary seed dispersal, whether internal (endozoochorous) or external (epizoochorous), and even more so in such secondary seed dispersal, there are many factors beyond the dispersal itself that must be satisfactory before a crop seed can germinate, and establish and grow from a seedling into a mature plant, and further become a reproductive plant or member of a population of these plants (Clausen et al., 2002; Gressel, 2005; Nathan and Muller-Landau, 2000; Wang and Smith, 2002). In addition to the usual series of challenges for wild plants, crop plants generally have inherent derived characteristics that make them successful in cultivation but consequently, often less fit when not tended. This domestication syndrome (Gepts, 2004; Warwick and Stewart, 2005) considerably reduces and limits the likelihood of successful germination and establishment.

\section{Seed adhesion and transport}

Few studies have evaluated the external, mechanical dispersal of seeds on the feathers or other body parts of birds. Sorensen (1986) reviewed the adhesion to birds of seeds with hooked, barbed or viscidly adhesive fruits. In a study of wild waterbirds at two wetland locations, Figuerola and Green (2002b) found that 35 and $100 \%$ of the birds trapped were externally carrying plant and/or invertebrate propagules respectively. Seeds of 1 to 15 or more wild plant species were found adhering primarily to plumage, but also feet. Nearly $59 \%$ of the mallards (10 of 17) had usually 1 or 2 seeds adhering to plumage, or also feet.

Many commercial agriculture seeds, including maize, rice and safflower, have relatively smooth seeds and thus do not attach easily to bird feathers or other body parts. In our study, no seeds were found on feathers, and there were only four instances of seeds (of barley, safflower and rice) found attached to the muddy feet or legs of birds (pheasants and pigeons) (Tab. 5). We never saw wet soil attached to the feet or legs of mallards. Pheasants, pigeons and blackbirds have less foot surface area and so are more likely to sink into wet soil, which then possibly adheres more easily to their feet or legs, but for varying durations. A few crop seeds caught in adherent soil could be transported off site, perhaps even for long distances (Bellrose and Sieh, 1960; Clausen et al., 2002; Knittle et al., 1987), and then possibly could germinate and establish - if encountering favorable conditions.

Possibly, some birds that hoard or cache food could be another route to transport pharmaceutical and industrial crop seeds off site to where they might germinate and establish (Martin et al., 1951/1961; Vander Wall, 1990). Jays, crows and ravens (Corvidae) are among the birds that collect and cache seeds at scattered locations (Turcek and Kelso, 1968).

\section{CONCLUSIONS}

Viable commercial agriculture seeds from maize, barley, safflower and rice crops can be dispersed by farmland birds, but the potential and the frequency are low. Primary dispersal via the digestive tract is very unlikely. The potential for secondary dispersal via a carcass also is quite low because of the relatively low number of viable seeds in the digestive tract and mortality rate of these species when seeds are viable. The potential for external dispersal is somewhat higher, but greatly dependent on the circumstances. Likelihood of establishment after crop seed dispersal remains unknown. Additional laboratory research would be needed to determine the germination rate of crop seeds recovered from caged birds after exposing the seeds to representative environmental conditions (e.g. Nelms and Twedt, 1996). Field research is necessary to monitor the species and numbers of birds at proposed experimental pharmaceutical and industrial crops sites and determine the typical extent of crop seed removal by birds from such proposed sites. Isolating pharmaceutical and industrial planting locations away from commercial agriculture food/feed crops helps reduce the possibility of seeds being transported, germinating, establishing, and reproducing in similar agricultural sites (Howard and Hood, 2007).

\section{MATERIALS AND METHODS}

Five experiments were conducted to determine if (1) viable seeds of commercial maize, barley, safflower and rice pass through the digestive tract of captive mallards, ring-necked pheasants, red-winged blackbirds and rock pigeons; (2) seeds of these four crops that were recovered from the esophagus/crop and gizzard of these four farmland bird species remained viable; and (3) viable seeds of these four crops can be physically transported on feet and feathers of these four bird species.

The experiments were conducted at the U.S. Department of Agriculture, National Wildlife Research Center (NWRC) in Fort Collins, Colorado, USA in the Outdoor 
Animal Research Facility over a 6-month (spring-fall) period in 2006. Mallards (male), pheasants (male) and pigeons (unknown gender) were obtained from commercial sources. Wild blackbirds (male) were captured with cannon nets (Dill, 1969) in the vicinity of Fort Collins. One-hundred and fifty birds of each species were quarantined for 14 days before testing. Certified seed from commercial sources was used during quarantine and for all experiments. Water was always available ad libitum during quarantine and all experiments. During quarantine, birds were offered a daily fresh maintenance diet of maize, barley, safflower, rice, and game-bird starter feed (which had none of the cultivated seeds) for the first 7 days and the same diet without the starter feed for the following 7 days. Following quarantine, 40 birds of each species were randomly selected, weighed, banded and selected for inclusion in one of three experiments. A sampling time of $24 \mathrm{~h}$ was provided for passage of the commercial seeds, although their digestion is believed to be much shorter (e.g. Clark and Gentle, 1990). In reported experimental studies with captive mallards in which the feces were collected every $4 \mathrm{~h}$, mean retention time of seeds of wild fennel-leaf/sago false pondweed was $7.7 \pm 1.3 \mathrm{~h}$, and no intact seeds were recovered after $60 \mathrm{~h}$ (Charalambidou et al., 2005). In a similar study, all seeds of wild Eurasian arrowhead Sagittaria sagittifolia $\mathrm{L}$. were recovered within 4-12 h, but a few seed-like drupes of wild European burr-reed Sparganium emersum Rehmann were still recovered $60 \mathrm{~h}$ after ingestion (Pollux et al., 2005).

Blackbirds were not offered maize because this grain is too large for them to consume whole, even though they do feed heavily on maize ears during the ripening stage (Bernhardt et al., 1987). For narrative convenience, all our inclusive statements about consumption by the four bird species of the four seed types should be understood to implicitly exclude blackbirds and maize. Similarly, it should be understood that maize seed and barley seed transport by blackbirds were not tested (Tab. 5).

\section{Experiment 1: Repeated daily free feeding for 2 hours}

The birds of each species (mallards, pheasants, blackbirds, pigeons) were subdivided into four groups $(n=$ 10 /group), and the birds housed individually in $2 \mathrm{~m} \times$ $1 \mathrm{~m} \times 1 \mathrm{~m}$ cages. Each group was randomly assigned a daily diet of maize, barley, safflower or rice seed, to begin on day 4.

First, birds were acclimated to test cages for two days, during which they had access to fresh maintenance diet (combination of maize, barley, safflower, rice and gamebird starter feed). On day 3 at 07:00 h, the maintenance diet was removed from each cage and birds were deprived of all food (but not water) for $24 \mathrm{~h}$ to allow passage of the maintenance food (Sibbald, 1979). On each of the following three test days, starting at 07:00 h, each bird was presented with a food bowl containing its assigned seed for $2 \mathrm{~h}$. Mallards and pheasants were offered $200 \mathrm{~g}$, and blackbirds and pigeons $50 \mathrm{~g}$. Then the feed bowl was removed, the remaining feed and any spilled food collected and weighed, and a paper liner placed beneath the cage floor to catch feces. No further food was available until the following morning. Prior to feeding on the following test days, feces were collected from each cage and placed in a labeled paper bag. Consumption was determined by weighing the remaining seeds. Seed passage was determined by screening the feces, and collecting any seeds.

\section{Experiment 2: Orally gavaged seeds}

The birds and procedures for this phase were the same as those for experiment 1 except that once, on day 4 (at 07:00 h), each bird was orally gavaged (force-fed) with its assigned seed. We gavaged each mallard, pheasant and pigeon with 50 seeds, and each blackbird with 20 seeds. Single seeds were placed in the bird's mouth and a $5 \mathrm{~mm}$ diameter glass rod with rounded end used to gently push the seed down into the esophagus/crop. Then the bird's mouth was closed and the esophagus/crop massaged to prevent regurgitation. Before placing each bird back into its cage, a paper liner was placed beneath the cage floor to catch feces. Birds were checked within $30 \mathrm{~min}$ of gavaging to determine if any seeds were regurgitated. A bowl of game-bird starter feed $(250 \mathrm{~g}$ ) subsequently was placed in each cage (for $2 \mathrm{~h}$ ), along with water. Prior to similar free feeding on the following test days, feces from each cage were collected and placed in a labeled paper bag. Seed passage was determined by screening the feces, and collecting any respective seeds.

\section{Experiments $3 A$ and 3B: Single free feeding, for 2 hours or 6 hours}

Seeds, birds and procedures for this phase were the same as those for experiment 1 except as detailed here. As before, on day 4 (starting at 07:00 h) each bird was presented with a food bowl containing its assigned seed. Then, after $2 \mathrm{~h}$, five birds from each seed group were euthanized, and after $6 \mathrm{~h}$ the remaining five birds/group were euthanized. Birds were necropsied to remove ingested seeds from the esophagus/crop and the gizzard. Seeds from each bird were separated by esophagus/crop and gizzard, bagged and labeled. The respective recovered seeds by individual bird were placed in a Petri dish and put into an environmental chamber to determine 


\section{J.L. Cummings et al.}

germination rate, following procedures in U.S. Environmental Protection Agency (EPA) Ecological Effects Test Guidelines OPPTS 850.4100 (EPA, 1996).

\section{Experiment 4: Seed adhesion and transport}

Each species was subdivided into four groups, and each group randomly assigned a daily diet of maize, barley, safflower or rice seed, to begin on day 3. Mallards, pheasants, blackbirds and pigeons were housed in groups of $5,1,5$ and 10 birds, respectively, in $3 \mathrm{~m} \times 3 \mathrm{~m} \times 4 \mathrm{~m}$ cages. Birds were acclimated to the test cages as in experiment 1 .

On day 3 at 07:00 h, the maintenance diet was removed and each cage washed to remove any food items or feces. A stainless steel pan, $1.3 \mathrm{~m} \times 1.3 \mathrm{~m} \times 5 \mathrm{~cm}$, filled with soil (heavy clay or gumbo) from the state of Missouri's southeastern rice-growing region was placed in the center of the cage. Water was added to the soil and seeds placed on the soil surface (to simulate a crop field that combined adverse field conditions of wet soil with grain available). On day 3 starting at 08:00 $\mathrm{h}$, the assigned seeds for each group were scattered over the soil in each pan. Mallards and pheasants were offered $200 \mathrm{~g} / \mathrm{bird}$, and pigeons and blackbirds $50 \mathrm{~g} / \mathrm{bird}$ (water remained available). At 08:00, 12:00 and 16:00 h, birds were inspected visually from outside the cage to determine if seeds were collecting on feet or feathers or had been transported off the simulated field. At the conclusion on day 5, birds were captured, euthanized and inspected closely for attached seeds. Recovered seeds by individual birds were placed in a Petri dish and put into an environmental chamber following the same guidelines (EPA, 1996).

\section{ACKNOWLEDGEMENTS}

We thank M. Tobin and R. Engeman for review of the manuscript, and G. Gathright and his staff for animal care assistance. The U.S. Department of Agriculture, Animal and Plant Health Inspection Service, Biotechnology Regulatory Services, 4700 River Road, Riverdale, MD 20737, USA, funded the study. Research adhered to criteria outlined by the U.S. Animal Welfare Act (40 CFR, Par 160 Good Laboratory Practices Standards) and the NWRC Animal Care and Use Committee.

Received April 25, 2008; accepted October 3rd, 2008.

\section{REFERENCES}

APHIS/BRS (USDA Animal and Plant Health Inspection Service, Biotechnology Regulatory Services) (2007) Draft
Guidance for APHIS Permits for Field Testing or Movement of Organisms with Pharmaceutical or Industrial Intent. USDA/APHIS/BRS, Riverdale, Maryland, 42 p, http://www. aphis.usda.gov/brs/pdf/Pharma_Guidance.pdf

Bellrose FC, Sieh JG (1960) Massed waterfowl flights in the Mississippi flyway, 1956 and 1957. Wilson Bull. 72: 29-59

Bent AC (1932/1963) Life Histories of North American Gallinaceous Birds. Smithsonian Institution, U.S. National Museum Bull. 162 / Dover Publications, New York, 490 p

Bent AC (1958/1965) Life Histories of North American Blackbirds, Orioles, Tanagers, and Allies. Smithsonian Institution, U.S. National Museum Bull. 211 / Dover Publications, New York, 549 p

Bernhardt GE, Van Allsburg L, Dolbeer RA (1987) Blackbird and starling feeding behavior on ripening corn ears. Ohio J. Sci. 87: 125-129

Brugger KE, Dolbeer RA (1990) Geographic origin of redwinged blackbirds relative to rice culture in southwestern and southcentral Louisiana. J. Field Ornithol. 61: 90-97

Chakauya E, Chikwamba R, Rybicki EP (2006) Riding the tide of biopharming in Africa: considerations for risk assessment. South African J. Sci. 102: 284-288

Charalambidou I, Santamaría L (2002) Waterbirds as endozoochorous dispersers of aquatic organisms: a review of experimental evidence. Acta Oecol. 23: 165-176

Charalambidou I, Santamaría L, Langevoord O (2003) Effect of ingestion by five avian dispersers on the retention time, retrieval and germination of Ruppia maritima seeds. Functional Ecol. 17: 747-753

Charalambidou I, Santamaría L, Jansen C, Nolet BA (2005) Digestive plasticity in mallard ducks modulates dispersal probabilities of aquatic plants and crustaceans. Functional Ecol. 19: 513-519

Clark RG, Gentle GC (1990) Estimates of grain passage time in captive mallards. Canad. J. Zool. 68: 2275-2279

Clausen P, Nolet BA, Fox AD, Klaassen M (2002) Longdistance endozoochorous dispersal of submerged macrophyte seeds by migratory waterbirds in northern Europe - a critical review of possibilities and limitations. Acta Oecol. 23: 191203

Cooke WW (1940) Bird Migration. U.S. Dept. Agric. Bull. 185 : $1-47$

Cummings JL, Shwiff SA, Tupper SK (2005) Economic impacts of blackbird damage to the rice industry. In Nolte DL and Fagerstone KA, eds, Proceedings of the 11th Wildlife Damage Management Conference, Wildlife Damage Management Working Group of The Wildlife Society, Fort Collins, Colorado, pp 317-322

Dalal M, Dani RG, Kumar PA (2006) Current trends in the genetic engineering of vegetable crops. Sci. Hort. 107: 215225

Desai BB (2004) Seeds Handbook: Biology, Production, Processing, and Storage, 2nd edn, Marcel Dekker, New York, $787 \mathrm{p}$

DeVault TL, Rhodes Jr OE, Shivik JA (2003) Scavenging by vertebrates: behavioral, ecological, and evolutionary 
perspectives on an important energy transfer pathway in terrestrial ecosystems. Oikos 102: 225-234

Dill HH (1969) A Field Guide to Cannon Net Trapping. U.S. Department of the Interior, Bureau of Sport Fisheries and Wildlife, $18 \mathrm{p}$

Dolbeer RA (1978) Movement and migration patterns of redwinged blackbirds: a continental overview. Bird-Banding 49: 17-34

Einsiedel EF, Medlock J (2005) A public consultation on plant molecular farming. AgBioForum 8: 26-32

Elbehri A (2005) Biopharming and the food system: examining the potential benefits and risks. AgBioForum 8: $18-25$

EPA (United States Environmental Protection Agency) (1996) Ecological Effects Test Guidelines: OPPTS 850.4100 Terrestrial Plant Toxicity, Tier I (Seedling Emergence). EPA 712-C-96-153, $6 \mathrm{p}$

Figuerola J, Green AJ (2002a) Dispersal of aquatic organisms by waterbirds: a review of past research and priorities for future studies. Freshwater Biol. 47: 483-494

Figuerola J, Green AJ (2002b) How frequent is external transport of seeds and invertebrate eggs by waterbirds? A study in Doñana, SW Spain. Archiv. Hydrobiol. 155: 557-565

Figuerola J, Green AJ, Santamaría L (2002) Comparative dispersal effectiveness of wigeongrass seeds by waterfowl wintering in south-west Spain: quantitative and qualitative aspects. J. Ecol. 90: 989-1001

Figuerola J, Green AJ, Santamaría L (2003) Passive internal transport of aquatic organisms by waterfowl in Doñana, south-west Spain. Global Ecol. Biogeogr. 12: 427-436

Fischer R, Stoger E, Schillberg S, Christou P, Twyman RM (2004) Plant-based production of biopharmaceuticals. Current Opinion Plant Biol. 7: 152-158

Floss DM, Falkenburg D, Conrad U (2007) Production of vaccines and therapeutic antibodies for veterinary applications in transgenic plants: an overview. Transgenic Res. 16: 315-332

Freese B, Hansen M, Gurian-Sherman D (2004) Pharmaceutical Rice in California: Potential Risks to Consumers, the Environment and the California Rice Industry. Friends of the Earth (FOE), Center for Food Safety, Consumers Union, and Environment California, FOE, Washington, DC, $19 \mathrm{p}$

Gepts P (2004) Crop domestication as a long-term selection experiment. Plant Breed. Rev. 24: 1-44

Goldstein DA, Thomas JA (2004) Biopharmaceuticals derived from genetically modified plants. QJM: Internat. J. Med. 97: 705-716

Green AJ, Figuerola J, Sánchez MI (2002) Implications of waterbird ecology for the dispersal of aquatic organisms. Acta Oecol. 23: 177-189

Gressel J, ed (2005) Crop Ferality and Volunteerism. CRC Press, Boca Raton, Florida, USA, $422 \mathrm{p}$

Han M, Su T, Zu Y-G, An Z-G (2006) Research advances on transgenic plant vaccines. Acta Genetica Sinica 33: 285-293

Herdt RW (2006) Biotechnology in agriculture. Annual Rev. Environ. Resour. 31: 265-295
Holland JM, Hutchison MAS, Smith B, Aebischer NJ (2006) A review of invertebrates and seed-bearing plants as food for farmland birds in Europe. Annals Appl. Biol. 148: 49-71

Howard JA, Hood EE (2007) Methods for growing nonfood products in transgenic plants. Crop Sci. 47: 1255-1262

Knittle CE, Linz GM, Johns BE, Cummings JL, Davis JE, Jaeger MM (1987) Dispersal of male red-winged blackbirds from two spring roosts in central North America. J. Field Ornithol. 58: 490-498

Ma JK-C, Chikwamba R, Sparrow P, Fischer R, Mahoney R, Twyman RM (2005) Plant-derived pharmaceuticals - the road forward. Trends Plant Sci. 10: 580-585

Malone CR (1965) Dispersal of plankton: rate of food passage in mallard ducks. J. Wildl. Managem. 29: 529-533

Manley SW, Kaminski RM, Reinecke KJ, Gerard PD (2004) Waterbird foods in winter-managed ricefields in Mississippi. J. Wildl. Managem. 68: 74-83

Martin AC, Zim HS, Nelson AL (1951/1961) American Wildlife and Plants: A Guide to Wildlife Food Habits. McGraw-Hill Book Co., New York/Dover Publications, New York, $500 \mathrm{p}$

Mascia PN, Flavell RB (2004) Safe and acceptable strategies for producing foreign molecules in plants. Current Opinion Plant Biol. 7: 189-195

McAtee WL (1947) Distribution of seeds by birds. Amer. Midland Naturalist 38: 214-223

Mewett O, Johnson H, Holtzapffel R (2007) Plant Molecular Farming in Australia and Overseas. Bureau of Rural Sciences, Australian Government, Canberra, xvi $+47 \mathrm{p}$

Moschini GC (2006) Pharmaceutical and industrial traits in genetically modified crops: coexistence with conventional agriculture. Amer. J. Agric. Econ. 88: 1184-1192

Mueller MH, van der Valk AG (2002) The potential role of ducks in wetland seed dispersal. Wetlands 22: 170-178

Murphy DJ (2007) Improving containment strategies in biopharming. Plant Biotech. J. 5: 555-569 + Tables S1-S3 (17 p)

Nathan R, Muller-Landau HC (2000) Spatial patterns of seed dispersal, their determinants and consequences for recruitment. Trends Ecol. Evol. 15: 278-285

Nelms CO, Twedt DJ (1996) Seed deterioration in flooded agricultural fields during winter. Wildl. Soc. Bull. 24: 85-88

Nogales M, Medina FM, Valido A (1996) Indirect seed dispersal by the feral cats Felis catus in island ecosystems (Canary Islands). Ecography 19: 3-6

Nogales M, Quilis V, Medina FM, Mora JL, Trigo LS (2002) Are predatory birds effective secondary seed dispersers? Biol. J. Linnean Soc. 75: 345-352

NRC (Committee on Environmental Impacts Associated with Commercialization of Transgenic Plants, Board on Agriculture and Natural Resources, National Research Council) (2002) Environmental Effects of Transgenic Plants: The Scope and Adequacy of Regulation. National Academies Press, Washington, DC, $342 \mathrm{p}$

Peterson CA, Lee SL, Elliott JE (2001) Scavenging of waterfowl carcasses by birds in agricultural fields of British Columbia. J. Field Ornithol. 72: 150-159 
Peterson RKD, Arntzen CJ (2004) On risk and plant-based biopharmaceuticals. Trends Biotech. 22: 64-66

Pierson TA, Cobb RG, Scanlon PF (1976) Crop contents of rock doves in Virginia. Wilson Bull. 88: 489-490

Pinowski J, Summers-Smith JD, eds (1990) Granivorous Birds in the Agricultural Landscape. Polish Scientific Publishers, Warsaw, $360 \mathrm{p}$

Pollux BJA, Santamaría L, Ouborg NJ (2005) Differences in endozoochorous dispersal between aquatic plant species, with reference to plant population persistence in rivers. Freshwater Biol. 50: 232-242

Powers KD, Noble RE, Chabreck RH (1978) Seed distribution by waterfowl in southwestern Louisiana. J. Wildl. Managem. 42: 598-605

Proctor VW (1964) Viability of crustacean eggs recovered from ducks. Ecology 45: 656-658

Proctor VW (1966) Dispersal of desmids by waterbirds. Phycologia 5: 227-232

Prosser P, Hart ADM (2005) Assessing potential exposure of birds to pesticide-treated seeds. Ecotoxicology 14: 679-691

Ridley HN (1930) The Dispersal of Plants Throughout the World. L. Reeve \& Company, Ashford, Kent, Great Britain, $744 \mathrm{p}$

Rose E, Nagel P, Haag-Wackernagel D (2006) Spatiotemporal use of the urban habitat by feral pigeons (Columba livia). Behav. Ecol. Sociobiol. 60: 242-254 + S1 (1 p)

Santamaría L, Charalambidou I, Figuerola J, Green AJ (2002) Effect of passage through duck gut on germination of fennel pondweed seeds. Archiv. Hydrobiol. 156: 11-22

Scheller J, Conrad U (2005) Plant-based material, protein and biodegradable plastic. Current Opinion Plant Biol. 8: 188 196

Sibbald IR (1979) Passage of feed through the adult rooster. Poultry Sci. 58: 446-459

Smallwood M (2006) The impact of genomics on crops for industry. J. Sci. Food Agric. 86: 1747-1754
Sorensen AE (1986) Seed dispersal by adhesion. Annual Rev. Ecol. System. 17: 443-463

Spök A (2007) Molecular farming on the rise - GMO regulators still walking a tightrope. Trends Biotech. 25: 74-82

Stafford JD, Kaminski RM, Reinecke KJ, Manley SW (2006) Waste rice for waterfowl in the Mississippi Alluvial Valley. J. Wildl. Managem. 70: 61-69

Swank WG (1944) Germination of seeds after ingestion by pheasants. J. Wildl. Managem. 8: 223-231

Teli NP, Timko MP (2004) Recent developments in the use of transgenic plants for the production of human therapeutics and biopharmaceuticals. Plant Cell Tissue Organ Cult. 79: $125-145$

Traveset A (1998) Effect of seed passage through vertebrate frugivores' guts on germination: a review. Perspectives Plant Ecol. Evol. System. 1: 151-190

Turcek FJ, Kelso L (1968) Ecological aspects of food transportation and storage in the Corvidae. Commun. Behav. Biol., Part A 1: 277-297

UCS (Union of Concerned Scientists) (2006) Position Paper: Pharmaceutical and Industrial Crops. Union of Concerned Scientists, Washington, DC, $23 \mathrm{p}$

van der Pijl L (1982) Principles of Dispersal in Higher Plants, 3rd edn, Springer-Verlag, Berlin and New York, $215 \mathrm{p}$

Vander Wall SB (1990) Food Hoarding in Animals. University of Chicago Press, Chicago, $453 \mathrm{p}$

Wang BC, Smith TB (2002) Closing the seed dispersal loop. Trends Ecol. Evol. 17: 379-385

Warwick SI, Stewart Jr CN (2005) Crops come from wild plants - how domestication, transgenes, and linkage together shape ferality. In Gressel J, ed, Crop Ferality and Volunteerism, CRC Press, Boca Raton, Florida, USA, pp 9-30

Yusibov V, Rabindran S, Commandeur U, Twyman RM, Fischer R (2006) The potential of plant virus vectors for vaccine production. Drugs R. D. 7: 203-217 